DE

M E D I C I N A

T R O P I C A L

$\mathrm{DE}$

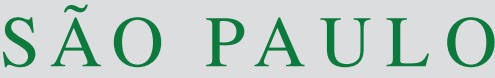

JOURNAL OF THE SÃO PAULO INSTITUTE OF TROPICAL MEDICINE

\section{American tegumentary leishmaniasis: epidemiological and molecular characterization of prevalent Leishmania species in the State of Tocantins, Brazil, 2011-2015}

\author{
Carina Scolari Gosch ${ }^{1,2}$, Cálita Pollyanna Marques², Bruna Silva Resende, \\ Joandson dos Santos Souza1, Ray Ameida da Silva Rocha1, Deyse Sabrinne \\ Souza Lopes ${ }^{1}$, Marcelo Scolari Gosch ${ }^{2}$, Fátima Ribeiro Dias ${ }^{2}$, Miriam Leandro \\ Dorta $^{2}$
}

\section{ABSTRACT}

Determination of the epidemiological profile of the American tegumentary leishmaniasis (ATL) and identification of Leishmania species that are prevalent in the State of Tocantins were carried out through a retrospective and descriptive study based on data reported in SINAN, in the period from 2011 to 2015. Molecular techniques such as PCR-RFLP and PCR-G6PD to amplify Leishmania DNA were performed on stored on Giemsa-stained slides from lesion scarifications of ATL patients who were amastigote-positive by the direct microscopic examination. There were 1,434 ATL cases in Tocantins reported in this period. The highest incidence was reported in men aged over 60 years, rural residents, the most affected ethnic group was mixed ethnicity (mixed black and white) and the ones with lower education. The predominant clinical form was cutaneous, being diagnosed mainly by laboratory methods. Pentavalent antimonial was effective in resolving cases. The predominant species found in 271 analyzed samples from 32 municipalities located in 8 different health regions of Tocantins was Leishmania (Viannia) braziliensis. Identifying the epidemiological profile and characterizing the Leishmania spp species on regional level is essential to establish control and prevention behaviors, minimizing the number of cases and treatment resistance, recurrence and evolution to mucosal forms.

KEYWORDS: Leishmaniasis. American tegumentary leishmaniasis. Cutaneous leishmaniasis. Epidemiology.

\section{INTRODUCTION}

American tegumentary leishmaniasis (ATL) is a parasitic disease caused by protozoa of the genus Leishmania spp. It is one of the six most prevalent infectious and parasitic diseases on the planet, considered a public health problem by the World Health Organization (WHO). On average, WHO estimates that, every year, 350 million people are at risk to contracting the disease. In Brazil, approximately 35,000 new cases are notified per year ${ }^{1-3}$.

In 2003, ATL autochthony was confirmed in all the federal units of Brazil ${ }^{4}$. The North, Northeast and Midwest regions have the highest number of reported cases of ATL with $46.08 \%, 26.56 \%$ and $15.14 \%$ in relation to the total number of cases reported in 2015, respectively ${ }^{5}$. In the State of Tocantins (TO), the incidence rate of ATL in 2012 was 31.18 cases per 100,000 inhabitants, well above the national rate of 11.86 cases per 100,000 inhabitants $^{6}$. The central region of the State, where health centers of the municipalities of Palmas, Paraíso, Guaraí and Porto Nacional 
are located, concentrated the largest number of reported cases, accounting for approximately $60.0 \%$ of the cases reported in $2015^{7}$.

Clinically, ATL corresponds to some forms of disease that are broadly classified as cutaneous, disseminated cutaneous, diffuse cutaneous and mucocutaneous. The incidence is mainly associated with areas of precarious socioeconomic conditions and with low levels of medical-sanitary infrastructure, deforestation and uncontrolled urbanization as the main causal factors of the disease expansion ${ }^{8,9}$.

Due to the great territorial extension of the country and the presence of geographic areas with particular characteristics, the epidemiology of infection may be different in certain regions of Brazil. This reality represents a challenge for national disease control programs and, for this reason, the Ministry of Health has developed the ATL Surveillance Program with the main objective of diagnosing and treating the detected cases early, in addition to focusing on the identification and monitoring of the Brazilian territory with higher epidemiological prevalence 4 . Thus, characterization of the epidemiological profile of each endemic region is necessary for the establishment of specific strategies of prevention and control of ATL adapted to different realities of each locality, as well as the identification of the etiological agent for the institution of more efficient therapeutic schemes to the existing species in each region, minimizing the treatment resistance, the number of relapses and evolution to mucosal forms. Thus, the objective of this work is to outline the epidemiological profile of ATL and identify the species of Leishmania prevalent in the State of Tocantins.

\section{MATERIAL AND METHODS}

\section{Health regionalization in Tocantins}

The State of Tocantins is in the Northern region of Brazil, with an area of $277,720.520 \mathrm{~km}^{2}$ and an estimated population of $1,496,880$ inhabitants in $2014^{10}$. It is composed of 139 municipalities and these are divided into eight health regions ${ }^{11}$, with the objective of promoting the organization of health actions and services based on the epidemiological profile, economic and cultural partnership, as well as infrastructure and access to each region. The eight regional health centers are: Augustinópolis, Araguaina, Guaraí, Paraíso, Palmas, Porto Nacional, Gurupi and Dianópolis (Figure 1).

\section{Characterization of the epidemiological profile of ATL}

Epidemiological data of ATL in Tocantins were made up of all the autochthonous cases of ATL in humans, diagnosed and notified to the Notification of Injury Information System (SINAN), referring to the eight regions of Health - TO, in the period from 2011 to 2015. Official notification data were provided by the Department of Technical Assistance of Leishmaniasis SVPPS / DVEDVZ / GDVZ of the State Department of Health of Tocantins (SESAU-TO). The variables used were sex, age, education, ethnic group, area of residence, confirmation criterion, evolution, clinical form, type of entry, occupation, initial drug administered.

\section{Molecular characterization of Leishmania species}

For identification of the Leishmania species prevalent in the State of Tocantins, 271 cases of ATL, confirmed by amastigote positivity in direct microscopic examination of Giemsa-stained slides specimens from lesion scarifications (DME), were enrolled from 32 different municipalities homogeneously distributed in the eight health regions of the State. The average number of samples per health region was 30 Giemsa-stained slides. Slides were provided by the ATL quality control department of the Central Laboratory of Public Health of Tocantins (LACEN-TO).

DNA extraction from Giemsa-stained slides was conducted using the commercial extraction kit protocol Illustra $^{\mathrm{TM}}$ blood genomic Prep Mini Spin (GE Healthcare ${ }^{\circledR}$, UK Limited, Buckinghamshire, Code: 28-9042-64), according to the manufacturer's instructions.

Leishmania DNA was amplified from 271 of the DNA samples using primers from the kinetoplast minicircle DNA designed by Passos et al. ${ }^{12}$. Amplification products were visualized on silver-stained $8 \%$ polyacrylamide gels. Primers were designed to amplify the conserved region of the minicircle of Leishmania kDNA producing fragments of $120 \mathrm{bp}$ for L. (Viannia) subgenus and $116 \mathrm{bp}$ for $L$. (L.) Leishmania, as described by Volpini et al. ${ }^{13}$. For confirmation of the subgenus Viannia, PCR products were digested with Hae III restriction enzyme, which has a specific site for subgenus Viannia. The $120 \mathrm{bp} \mathrm{PCR} \mathrm{product}$ of $L$. (V.) produces two fragments of $40 \mathrm{bp}$ and $80 \mathrm{bp}$, and the enzyme does not digest the $L$. (L.) amazonensis. After digestion,fragments were visualized in $15 \%$ silver-stained polyacrylamide gels as described by Volpini et al. ${ }^{13}$.

The identification of $L(V$.) braziliensis species was carried out by amplification of the enzyme glucose-6phosphate dehydrogenase (G6PD; EC 1.1.1.49), according to Castilho et al. ${ }^{14}$. In the assay, DNA was extracted as described above, then amplification was performed using primers that specifically amplify G6PD sequences of $L$. (V.) braziliensis (ISVB and ISVC). Amplification products were visualized on silver-stained $8 \%$ polyacrylamide gels. 


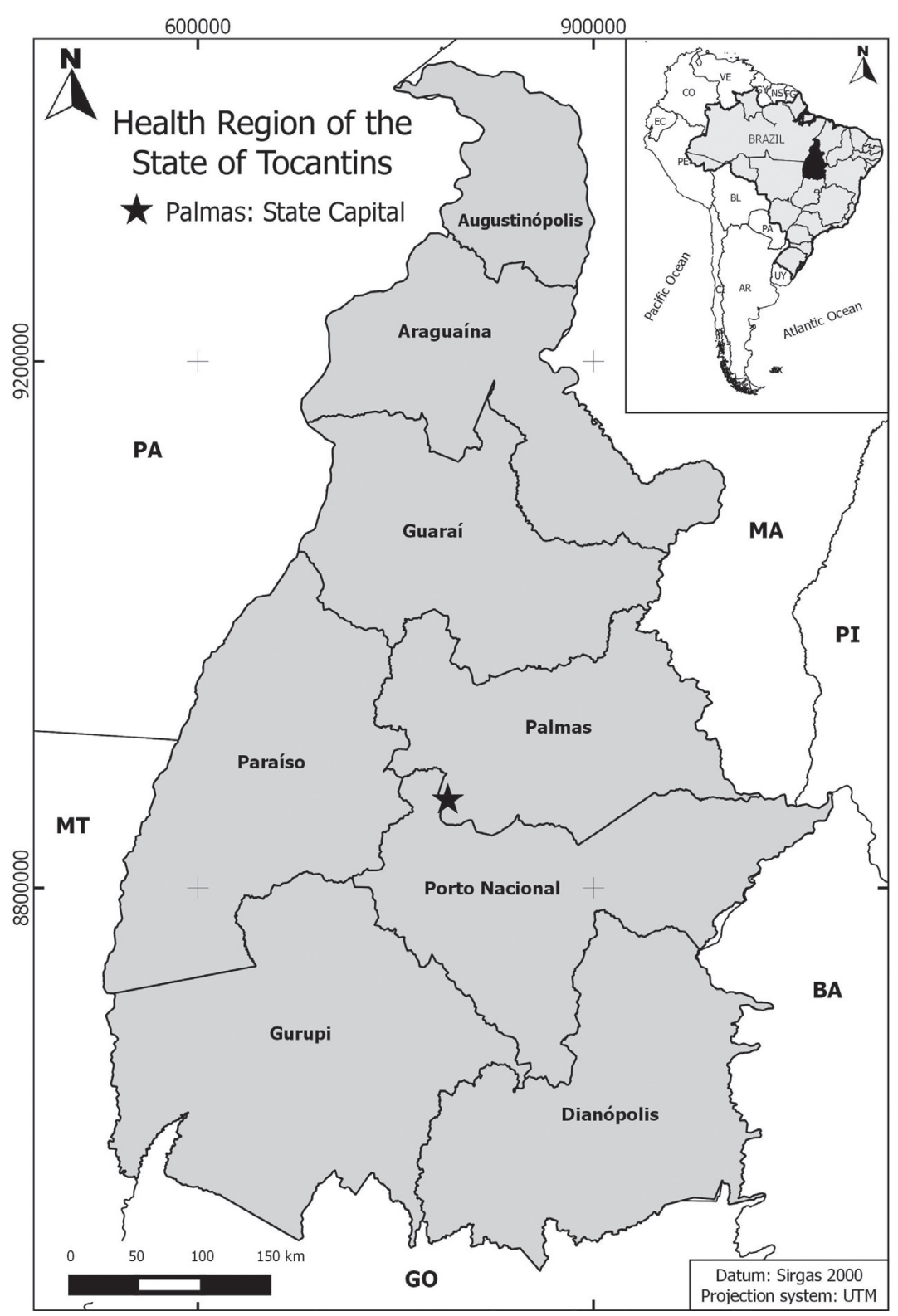

Figure 1 - Location of the eight health regions in the State of Tocantins in Brazil, South America. They are the regions of Augustinópolis, Araguaína, Guaraí, Paraíso, Palmas, Porto Nacional, Gurupi and Dianópolis

\section{Data analysis}

The database of records from SINAN - TO was used to search for information on ATL. Data were arranged statistically in absolute and relative frequencies and incidence rates using Microsoft Office Excel $^{\circledR}$ version 2013, the found values were presented in tables and graphs allowing a better visualization of their evaluation. Maps were built using the Qgis program Sirgas 2000 version.

The present study was approved by the Research Ethics Committee (CEP) of the Clinical Hospital of the Federal University of Goiás - GO under the $\mathrm{N}^{\circ}$ 35963214.6.0000.5078.

\section{RESULTS}

Tocantins reported a total of 1,434 autochthonous cases of ATL to SINAN in the period from 2011 to 2015. The number of municipalities with case records reported to SINAN increased progressively over a 5-year period, characterizing a territorial expansion of the disease in the State. In 2011, from the total of 139 municipalities in the State of Tocantins, 81 cases of ATL were reported to SINAN, and at the end of the study years, only 6 municipalities had no cases of ATL (Figure 2). The health regions with the highest incidences of ATL per 100,000 inhabitants were Paraíso regions 36.5 cases; Porto Nacional, 34.0 cases; 
Dianópolis, 28.7 cases and Guaraí, 26.5 cases (Figure 3). Municipalities with the highest incidences of reported cases per 100,000 inhabitants were: Tocantínea (178.0 cases), Ponte Alta do Tocantins (140.0 cases), Lavandeira (127.0 cases) and Araguacema (123.0 cases). The year with the highest frequency of ATL notification was 2014 (Figure 4).

Socio-demographic characteristics of reported cases (Table 1) revealed that the highest incidence of cases occurs in individuals: male (28.6); over 60 years of age (32.4); living in rural areas (38.5). In terms of ethnicity, education and disease-to-work ratio, there was a higher frequency of ATL in the mixed population (69.1\%), with lower educational level (23.4\%) and no disease at work $(73.8 \%)$.

The classification of disease and the clinical, diagnostic, therapeutic and evolution characteristics of cases were

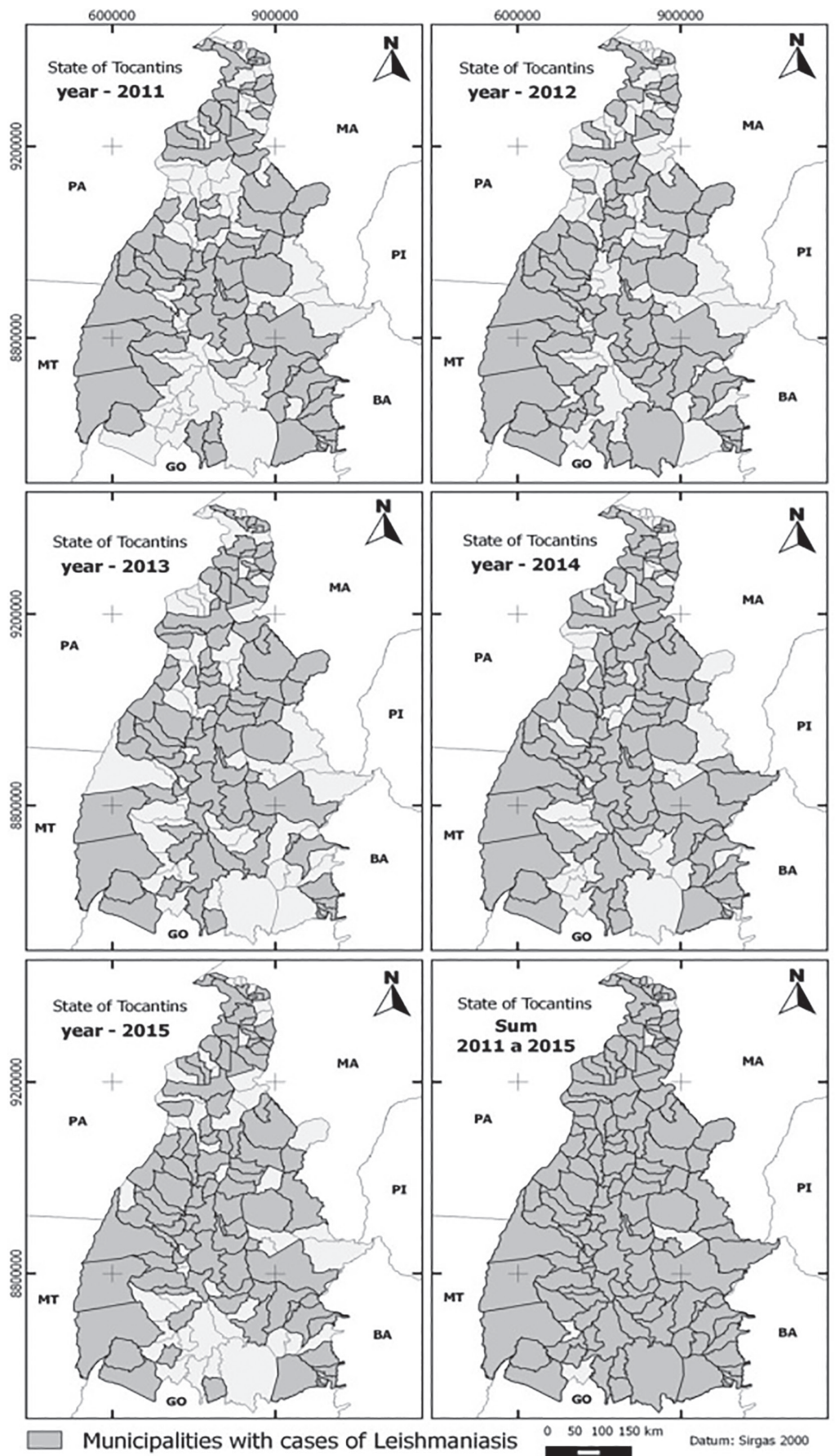

Figure 2 - Geographical distribution of ATL in the State of Tocantins. Location of municipalities reporting cases of ATL in humans at SINAN, from 2011 to 2015 . Number of municipalities reporting ATL cases in the years of study: 2011 (81 municipalities), 2012 (84 municipalities), 2013 (85 municipalities), 2014 (96 municipalities), 2015 (86 municipalities) 


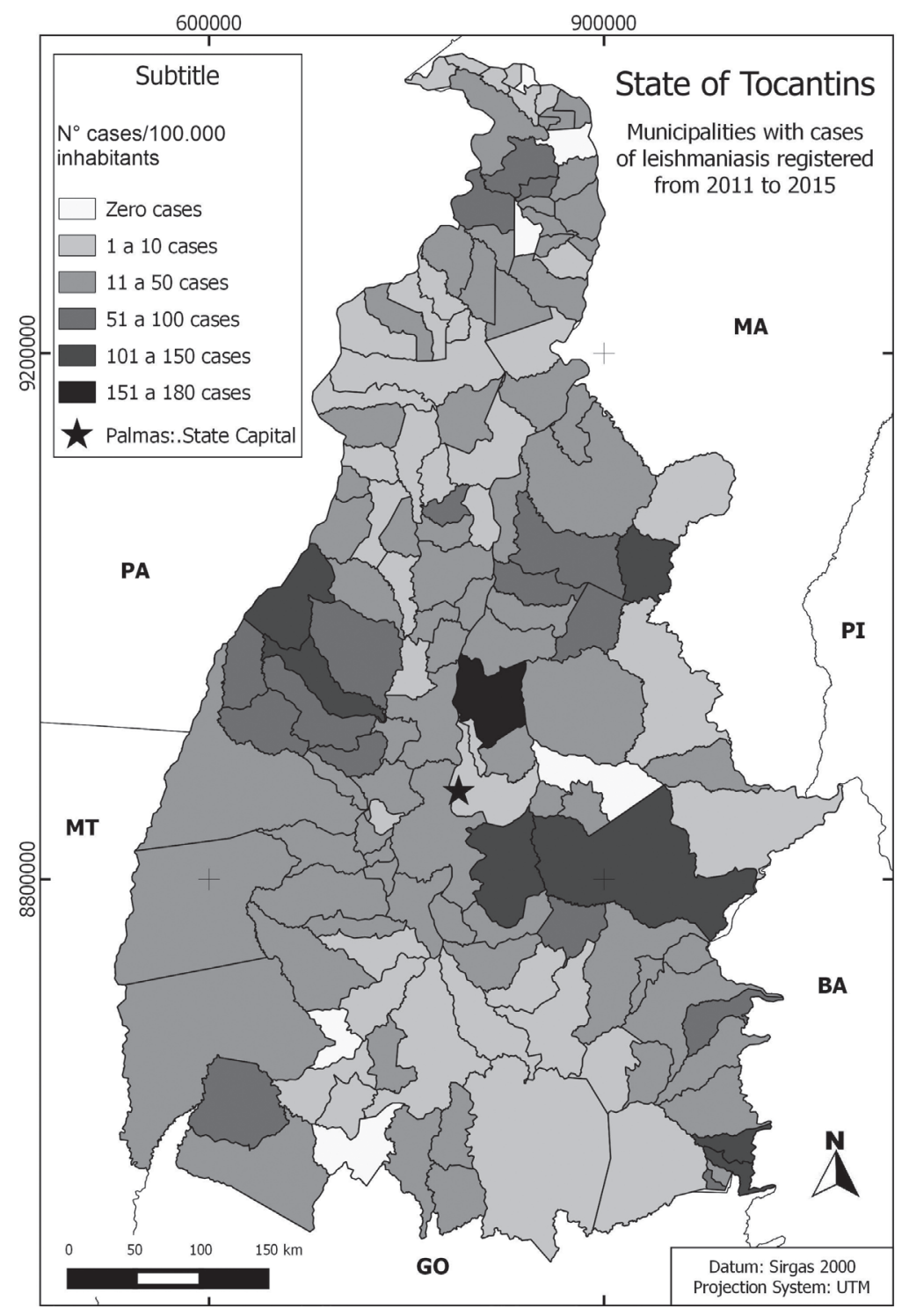

Figure 3 - ATL notification incidence by municipality. Stratification of municipalities by incidence of reported cases of ATL, period 2011-2015, performed in the eight health regions that make up the State of Tocantins, in Brazil

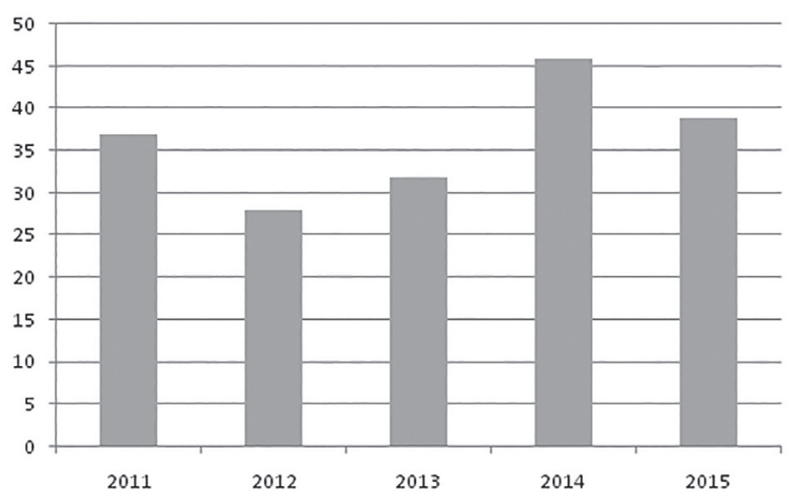

Figure 4 - Frequency of ATL notifications per year. The stratification per year of reported ATL cases, period 2011-2015, performed in the eight health regions that make up the State of Tocantins, Brazil evaluated (Table 2). ATL cases were classified as new in $92.6 \%$ of reports. These cases were confirmed mainly by laboratory tests $(74.0 \%)$ and the predominant clinical form was cutaneous in $94.5 \%$ of the cases. Eighty percent of patients were treated with the first choice drug recommended by the Ministry of Health, pentavalent antimonial, and the cure rate was $85.0 \%$.

PCR-RFLP technique was used to identify Leishmania in 271 amastigote-positive Giemsa-stained slides that yielded positive results by direct microscopic examination, from patients of 32 different municipalities of the eight health regions of the State of Tocantins, 252 (92.0\%) samples were identified as belonging to the subgenus $L$. (Viannia) and 19 (8.0\%), to L. (L.) amazonensis species (Figure 5). 
Table 1 - Socio-demographic and epidemiological characteristics of ATL cases reported to SINAN in the State of Tocantins, Brazil, from 2011 to 2015

\begin{tabular}{|c|c|c|c|}
\hline \multirow[b]{2}{*}{ CHARACTERISTICS } & \multicolumn{3}{|c|}{ TOTAL } \\
\hline & $\mathbf{N}$ & $\%$ & $\begin{array}{c}\mathrm{N}^{\circ} \text { cases/ } \\
100.000 \\
\text { inhabitants }\end{array}$ \\
\hline \multicolumn{4}{|l|}{ Age Group } \\
\hline$<1$ year & 13 & 0.9 & 12.0 \\
\hline $1-19$ years & 262 & 18.3 & 9.6 \\
\hline 20-39 years & 578 & 40.3 & 22.8 \\
\hline $40-59$ years & 387 & 27.0 & 27.2 \\
\hline$>60$ years & 194 & 13.5 & 32.4 \\
\hline TOTAL & 1434 & 100.0 & - \\
\hline \multicolumn{4}{|l|}{ SEX } \\
\hline Male & 1076 & 75.0 & 26.8 \\
\hline Female & 358 & 25.0 & 9.9 \\
\hline TOTAL & 1434 & 100.0 & - \\
\hline \multicolumn{4}{|l|}{ Race } \\
\hline White & 190 & 13.2 & - \\
\hline Black & 158 & 11.0 & - \\
\hline Yellow & 12 & 0.9 & - \\
\hline Brown & 991 & 69.1 & - \\
\hline Indigenous & 57 & 4.0 & - \\
\hline$N / A^{*}$ & 26 & 1.8 & - \\
\hline TOTAL & 1434 & 100.0 & - \\
\hline \multicolumn{4}{|l|}{ Education } \\
\hline Illiterate & 71 & 4.9 & - \\
\hline $\begin{array}{l}\text { Elementary School In- } \\
\text { complete }\end{array}$ & 199 & 13.9 & - \\
\hline $\begin{array}{l}\text { Complete primary edu- } \\
\text { cation }\end{array}$ & 177 & 12.3 & - \\
\hline Incomplete high school & 335 & 23.4 & - \\
\hline Complete high school & 163 & 11.4 & - \\
\hline $\begin{array}{l}\text { Incomplete Higher Edu- } \\
\text { cation }\end{array}$ & 06 & 0.4 & - \\
\hline Full Higher Education & 32 & 2.2 & - \\
\hline$N / A^{*}$ & 384 & 26.8 & - \\
\hline Not applicable & 67 & 4.7 & - \\
\hline TOTAL & 1434 & 100.0 & - \\
\hline \multicolumn{4}{|l|}{ Work-Related IIIness } \\
\hline Yes & 94 & 6.5 & - \\
\hline No & 1057 & 73.8 & - \\
\hline$N / A^{*}$ & 283 & 19.8 & - \\
\hline TOTAL & 1434 & 100.0 & - \\
\hline \multicolumn{4}{|l|}{ Residence Zone } \\
\hline Rural & 603 & 42.0 & 35.5 \\
\hline Urban & 804 & 56.0 & 13.8 \\
\hline$N / A^{*}$ & 27 & 2.0 & - \\
\hline TOTAL & 1434 & 100.0 & - \\
\hline
\end{tabular}

${ }^{\star} \mathrm{N} / \mathrm{A}=$ Not applicable or Not available.

PCR-G6PD technique was used in 252 positive samples for Leishmania species belonging to the subgenus
Table 2 - Clinical, diagnostic, therapeutic and evolution of ATL cases reported to SINAN in the State of Tocantins, Brazil, from 2011 to 2015

\begin{tabular}{|c|c|c|}
\hline \multirow{2}{*}{ CHARACTERISTICS } & \multicolumn{2}{|c|}{ TOTAL } \\
\hline & $\mathbf{N}$ & $\%$ \\
\hline \multicolumn{3}{|l|}{ Input Type } \\
\hline New case & 1329 & 92.6 \\
\hline Relapse & 58 & 4.0 \\
\hline$N / A^{*}$ & 40 & 2.9 \\
\hline Transfer & 07 & 0.5 \\
\hline TOTAL & 1434 & 100.0 \\
\hline \multicolumn{3}{|l|}{ Confirmation Criteria } \\
\hline Laboratory & 1062 & 74.0 \\
\hline Clinical-epidemiological & 372 & 26.0 \\
\hline TOTAL & 1434 & 100.0 \\
\hline \multicolumn{3}{|l|}{ Clinical Form } \\
\hline Cutaneous & 1355 & 94.5 \\
\hline Mucosal & 79 & 5.5 \\
\hline TOTAL & 1434 & 100.0 \\
\hline \multicolumn{3}{|l|}{ Drug of First Choice } \\
\hline Pentavalent Antimony & 1155 & 80.6 \\
\hline Amphotericin B & 53 & 3.7 \\
\hline Pentamidine & 04 & 0.3 \\
\hline Others & 103 & 7.2 \\
\hline Not used & 32 & 2.2 \\
\hline$N / A^{*}$ & 87 & 6.0 \\
\hline TOTAL & 1434 & 100.0 \\
\hline \multicolumn{3}{|l|}{ Evolution } \\
\hline Cure & 1218 & 85.0 \\
\hline Abandonment & 31 & 2.2 \\
\hline Death by ATL & 04 & 0.3 \\
\hline Death by another cause & 09 & 0.6 \\
\hline Transfer & 09 & 0.6 \\
\hline Change of diagnosis & 22 & 1.5 \\
\hline$N / A^{*}$ & 141 & 9.8 \\
\hline TOTAL & 1434 & 100.0 \\
\hline
\end{tabular}

${ }^{\star} \mathrm{N} / \mathrm{A}=$ Not applicable or Not available.

Viannia and 226 (90.0\%) samples were positive for $L$. (V.) braziliensis species (Figure 6).

The identification of the territorial distribution of molecularly characterized Leishmania species has shown that $L$. (V.) braziliensis is present in the 32 municipalities analyzed from the 8 health regions and that $L$. $(L$.) amazonensis was found in only 7 municipalities, 6 of which are located in the central region of Tocantins State (Figure 7).

\section{DISCUSSION}

In the last decades, epidemiological studies have suggested changes in the epidemiological behavior of 


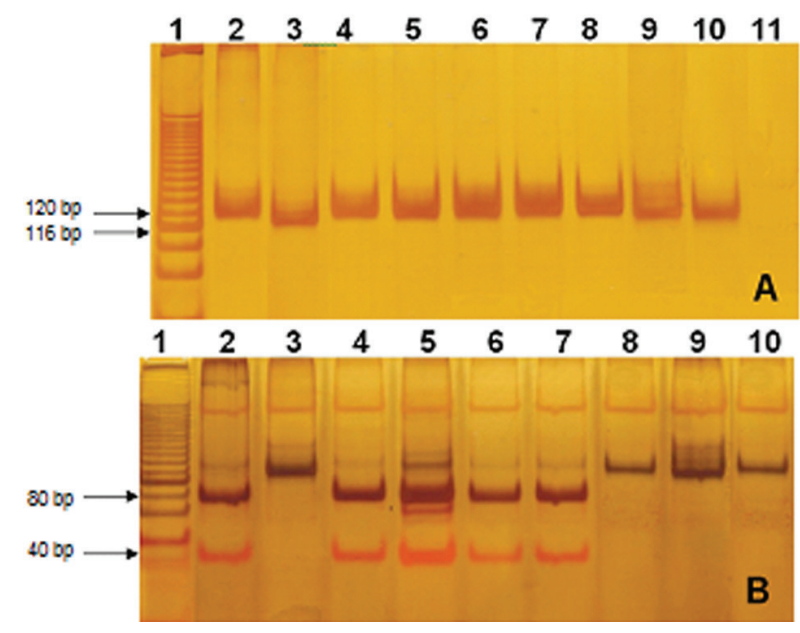

Figure 5 - Representative image of PCR amplified products from the conserved region of the Leishmania minicircle kDNA before and after Hae III digestion. In A: PCR amplicons, B: PCR product after HAE III digestion. In A1 and B1: molecular weight standard of $25 \mathrm{bp}$; In $\mathrm{A} 2$ and B2: L. (V.) braziliensis MHOM / BR / 1975 / M2903, WHO reference; In A3 and B3: L. (L.) amazonensis IFA / BR / 1967 / PH8, WHO reference; In A4-A10 and B4-B10: Isolate samples; In A11, negative control of the PCR. Polyacrylamide gel 8 and $15 \%$, respectively, stained by silver

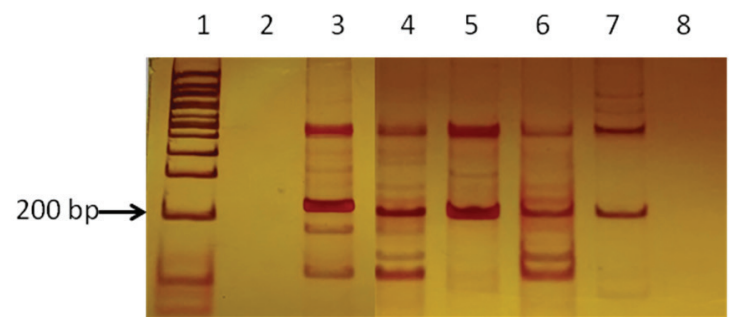

Figure 6 - PCR amplified products obtained with oligonucleotides G6PD-ISVC and G6PD-ISB. In 1: molecular weight standard of 100bp; 2: Negative Control; 3: L. (V.) braziliensis MHOM / BR / 1975 / M2903, WHO reference; 4-8: Samples. 8\% polyacrylamide gel stained with silver

ATL in Brazil. Initially, it was restricted to forest regions, having wild animals as reservoirs and where humans were accidentally infected when they eventually entered the forest. Progressively, more and more cases of ATL have been observed in practically deforested rural areas, in areas of ancient colonization, peri-urban regions and even in urban centers, being the disease related to adaptation of parasites and vectors to the environmental changes, having domestic animals as new reservoirs ${ }^{9}$. Thus, different epidemiological profiles, expressed by the endemic maintenance of cases from or close to outbreaks, the appearance of epidemic outbreaks associated with factors arising from the emergence of economic activities such as gold-digging, agricultural frontiers and extractivism, settlement of landless workers, constitute highly favorable environmental conditions for the transmission of disease ${ }^{4}$.
The study reveals that the State of Tocantins presents socio-demographic characteristics of ATL similar to those described in other studies demonstrating that ATL continues to be endemic with a higher incidence in men living in rural areas or exercising professional activity linked to the field, such as agriculture or livestock ${ }^{15-21}$, unlike other authors that showed greater endemicity in individuals living in urban areas ${ }^{22-27}$.

The presentation of disease was classified into three epidemiological profiles $\left.{ }^{17}: 1\right)$ purely wildlife ATL epidemic outbreaks associated with forest felling and disorderly forest exploration; 2) modified wild ATL (rural) - seasonal outbreaks, in areas with residual outbreaks of primary forest, at the interface of peridomiciliary areas and in forest areas, related to agriculture and linked to fluctuations in the population density of sand flies; and 3) periurban and urban ATL occuring in endemoepidemic, endodomicillary or peridomiciliary ways, in areas of ancient colonization, where the participation of domestic animals as reservoirs is suspected.

The State of Tocantins, as well as other regions of Brazil, presents a modified wild epidemiological profile. Having identified a greater cycle of ATL transmission in the rural environment: in humans who live or who develop activity linked to the field. To a lesser extent, a periurban and urban transmission cycle was also observedin individuals of both sexes and different age groups, with no expression of a professional standard related to disease, however, it is not possible to exclude the possibility of these individuals, to engage in tourism or leisure activities, such asfishing, hunting, camping, bathing in lakes and rivers, exposing them to environments compatible with the mode of transmission classically assigned to the infection.

The most commonly used method was the laboratory diagnosis (74.0\%), mainly the scraping of the lesion for the preparation of Giemsa-stained slides (57.5\%), followed by the Montenegro skin test (16.6\%) and histopathology $(8.8 \%)$. Although these tests are widely used and of low operational costs, in particular the Montenegro skin test and the Giemsa-stained slides, $15.6 \%$ did not had any of these tests performed to confirm the clinical suspicion. These and those who presented negative test results were classified exclusively by clinical-epidemiological criteria, totaling $26.0 \%$ of the suspected cases. This fact is acceptable since this method takes into account the characteristics of lesions and if the patient comes from an endemic region. However, an association between epidemiological, clinical and laboratory aspects would be ideal for the diagnosis of ATL, minimizing failures to detect new cases and change of diagnosis ${ }^{22}$.

In the present study, we verified a diagnosis change in 22 cases, classified exclusively by the clinical-epidemiological 


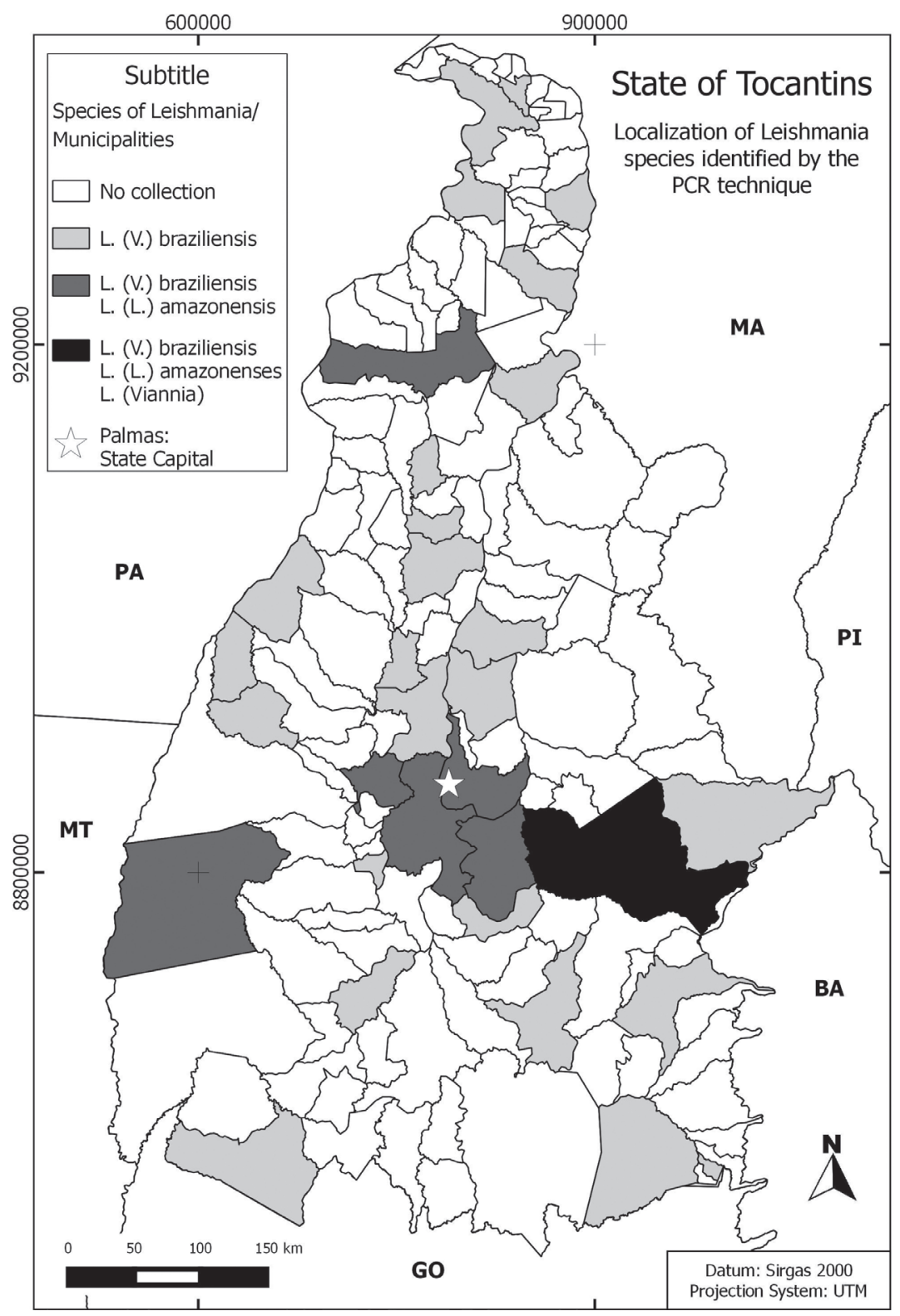

Figure 7 - Territorial distribution of Leishmania species in the State of Tocantins. Positive samples of DME were collected from 32 municipalities distributed homogeneously in the eight health regions of the State and characterized molecularly by PCR-RFLP and PCR-G6PD

form. This clearly demonstrates that non-use of existing laboratory resources exposes the patients to unnecessary risks since pentavalent antimonial therapy has a number of side effects, some of which are serious, such as cardiac arrhythmias ${ }^{28}$.

The clinical form of ATL was predominantly cutaneous (94.5\%), similar to the studies performed by Rocha $e t$ $a l . .^{25}$ and Xavier et $a l .{ }^{26}$, which also showed the cutaneous form as the clinical manifestation of higher incidence with 95.0\% and 96.0\%, respectively, in the States of Alagoas and Minas Gerais. Data also agree with those from the Ministry of Health, which estimates that only 3.0 to $5.0 \%$ of cases with skin lesions will develop the mucosal form of disease ${ }^{3}$.

The percentage of cure of all reported cases $(1,434)$ when analyzed globally is $85.0 \%$ (1218), consistent with what is found in other studies ${ }^{18,26,29,30}$. However, if only the confirmed cases are considered (- 22 with change of diagnosis), treated (- 31 who abandoned) and already closed (- 141 without outcome), there were 1,240 cases and consequently $98.2 \%$ of clinical cure after treatment and only $1.5 \%$ of drug resistance and $4.0 \%$ of recurrence, revealing that the standard treatment scheme is effective in this population, since the recurrence rate is below the mean of $4.6 \%{ }^{30}$.

Molecular characterization using Giemsa-stained 
slides identified that, in $90.0 \%$ of samples, the most prevalent species of Leishmania in the region was $L$. (V.) braziliensis and in $8.0 \%$ of samples, $L$. (L.) amazonensis species (Figure 6). PCR assay was developed on the basis of isoenzyme data and has been used as an identification $\operatorname{target}^{14}$. The test detected parasite DNA in Giemsa-stained slides from lesion scarification of ACL patients, all amastigote-positive by the direct microscopic examination. PCR discriminated L. (Viannia) braziliensis from the other sympatric species belonging to the same subgenus. This finding corroborates data ${ }^{31}$ from a study that identified as the predominant phlebotomine species in the peridomiciliary environment in Tocantins, Lutzomya whitmani, one of the main species incriminated by the transmission of $L$. (V.) braziliensis. In Brazil, L. (V.) braziliensis is the most widely species distributed in the country associated with cutaneous and mucosal manifestations of $\mathrm{ATL}^{3}$.

Similar data evidenced by our research group in the Midwest region of Brazil, where in Goiás and Mato Grosso, States bordering Tocantins, $93.5 \%$ of the identified species were $L$. (V.) braziliensis and $6.0 \%$ L. (L.) amazonenesi ${ }^{32}$. On the other hand, in the Amazon region, North of Brazil, the predominant species is $L$. (V.) guyanensi ${ }^{33}$.

The gradual increase in reported cases of ATL throughout the years of study, with a peak of notification in 2014 (355 cases), suggests a possible flaw in the surveillance and control actions of the disease in Tocantins. This fact justified the intensification of health surveillance measures related to leishmaniasis with the accomplishment of seven technical capacities regarding the surveillance and control actions of leishmaniasis in different municipalities of the State with high levels of notification, as well as the holding of the II discussion forum on leishmaniasis. These measures contributed to a general reduction in the number of cases of ATL in the year $2015^{34,35}$.

The ATL is a compulsory notification disease, so it is possible to know the actual number of affected individuals in a population however, the observation of a considerable percentage of White/Ignorant cases regarding the evolution of disease $(9,8 \%),(6.0 \%)$, or type of admission (2.9\%) is a limiting factor of the study and reveals the need for a better qualification of health service professionals who fill out the notification forms in order to reduce data inconsistencies and consequently improve the information system (SINAN).

Knowing the population affected by ATL in our country is important for effective measures of the disease control to be established. Differences in morbidity, response to treatment and prognosis, related to Leishmania species, evidenced the need to characterize the most prevalent parasite species in different regions of Brazil that have different epidemiological characteristics.

\section{FINANCING}

This study was part of the research project "Epidemiology of American Tegumentary Leishmaniasis: molecular diagnosis of leishmaniasis species in the Tocantins populations", funded by CNPq, in the FAPT/PPSUS Notice No 01/2014, coordinated by Prof. Dr. Miriam Leandro Dorta, located at the Faculdade Presidente Antônio Carlos - Porto Nacional (FAPAC/ ITPAC-PORTO).

\section{ACKNOWLEDGMENT}

To the State Department of Health of Tocantins for the authorization and provision of notification data. To those responsible for the quality control of the Central Laboratory of Tocantins (LACEN-TO) for providing the positive lesion scraping blades for direct parasitological examination of ATL.

\section{REFERENCES}

1. Bentes AA, Rodrigues DE, Carvalho E, Carvalho AL, Campos FA, Romanelli RM. Leishamniose tegumentar americana: um desafio diagnóstico na prática pediátrica. Rev Med Minas Gerais. 2015;25 Supl 6:S83-7.

2. Negrão GN, Ferreira ME. Considerações sobre a leishmaniose tegumentar americana e sua expansão no território brasileiro. Rev Percurso. 2014;6:147-68.

3. Brasil. Ministério da Saúde. Secretaria de Vigilância em Saúde. Manual de vigilância da leishmaniose tegumentar americana. $2^{\mathrm{a}}$ ed. Brasília: Ministério da Saúde; 2010. [cited 2016 Jul 18]. Available from: http://bvsms.saude.gov.br/bvs/publicacoes/ manual_vigilancia_leishmaniose_tegumentar_americana.pdf

4. Brasil. Ministério da Saúde. Secretaria de Vigilância em Saúde. Departamento de Vigilância Epidemiológica. Doenças infecciosas e parasitárias: guia de bolso. $8^{\mathrm{a}}$ ed. Brasília: Ministério da Saúde; 2010. [cited 2017 Nov 7]. Available from: http://bvsms.saude.gov.br/bvs/publicacoes/doencas_ infecciosas_parasitaria_guia_bolso.pdf

5. Brasil. Ministério da Saúde. Casos de leishmaniose tegumentar, Brasil, grandes regiões e unidades federadas. 1990 a 2015. [cited 2017 Nov 7]. Available from: http://portalarquivos.saude. gov.br/images/pdf/2016/novembro/07/LT-Casos.pdf

6. Brasil. Ministério da Saúde. Banco de Dados do Sistema Único de Saúde. Indicadores de morbidade: D.2.4 Taxa de incidência da leishmaniose tegumentar americana.. [cited 2017 Nov 7]. Available from: http://tabnet.datasus.gov.br/cgi/deftohtm. exe?idb2012/d0204.def

7. Brasil. Ministério da Saúde. Banco de Dados do Sistema Único de Saúde. Leihsmaniose tegumentar americana: casos 
confirmados notificados no Sistema de Informação de Agravos de Notificação - Tocantins. [cited 2017 Nov 7]. Available from: http://tabnet.datasus.gov.br/cgi/deftohtm.exe?sinannet/cnv/ ltato.def

8. Gontijo B, Carvalho ML. Leishmaniose tegumentar americana. Rev Soc Bras Med Trop. 2003;36:71-80.

9. Vale EC, Furtado T. Leishmaniose tegumentar no Brasil: revisão histórica da origem, expansão e etiologia. An Bras Dermatol. 2005;80:421-8.

10. Instituto Brasileiro de Geografia e Estatística. Estimativas da população residente no Brasil e unidades da Federação com data de referência em $1^{\circ}$ de julho de 2014. [cited 2017 Nov 8]. Available from: ftp://ftp.ibge.gov.br/Estimativas_de_ Populacao/Estimativas_2014/estimativa_dou_2014.pdf

11. Tocantins. Secretaria de Estado da Saúde. Comissão Intergestora Bipartite/CIB-TO. Secretaria Executiva. Resolução - CIB $\mathrm{N}^{\circ} 161 / 2012$, de 29 de agosto de 2012. Dispõe sobre a conformação das novas regiões de saúde do estado do Tocantins e as ações e serviços mínimos a serem ofertados nesses territórios. [cited 2017 Nov 7]. Available from: https:// central3.to.gov.br/arquivo/244723/

12. Passos VM, Lasmar EB, Gontijo CM, Fernandes O, Degrave W. Natural infection of a domestic cat (Felis domesticus) with Leishmania (Viannia) in the metropolitan region of Belo Horizonte, State of Minas Gerais, Brazil. Mem Inst Oswaldo Cruz. 1996;91:19-20.

13. Volpini AC, Passos VM, Oliveira GC, Romanha AJ. PCR-RFLP to identify Leishmania (Viannia) braziliensis and L. (Leishmania) amazonensis causing american cutaneous leishmaniasis. Acta Trop. 2004;90:31-7.

14. Castilho TM, Shaw JJ, Floeter-Winter LM. New PCR assay using glucose- 6 phosphate dehydrogenase for identification of Leihsmania species. J Clin Microbiol. 2003;41:540-6.

15. Oliart-Guzmán H, Martins AC, Mantovani SA, Braña AM, Delfino BM, Pereira TM, et al. Características epidemiológicas da leishmaniose tegumentar americana na fronteira amazônica: estudo retrospectivo em Assis Brasil, Acre. Rev Patol Trop. 2013;42:187-200.

16. Figueira LP, Soares FV, Naiff MF, Silva SS, Espir TT, Pinheiro FG, et al. Distribuição de casos de leishmaniose tegumentar no município de Rio Preto da Eva, Amazonas, Brasil. Rev Patol Trop. 2014;43:173-81.

17. França EL, Mandadori MN, França JL, Botelho AC, Ferrari CK, Honório-França AC. Aspectos epidemiológicos da leishmaniose tegumentar americana no município de Juína, Mato Grosso, Brasil. Sci Med (Porto Alegre). 2009;19:103-7.

18. Name RQ, Borges KT, Nogueira LS, Sampaio JH, Tauil PL, Sampaio RN. Estudo clínico, epidemiológico e terapêutico de 402 pacientes com leishmaniose tegumentar americana atendidos no Hospital Universitário de Brasília, DF, Brasil. An Bras Dermatol. 2005;80:249-54.
19. Silva AC, Cupolilo E, Volpini AC, Almeida R, Romero GA. Species diversity causing human cutaneous leishmaniasis in Rio Branco, state of Acre, Brazil. Trop Med Int Health. 2006;11:1388-98.

20. Cova BO, Fonseca EO, Santos RF, Santos PR, Natividade MS, Will RM. Aspectos ecoepidemiológicos da leishmaniose tegumentar americana no município de Ituberá, baixo sul da Bahia. Rev Baiana Saude Publica. 2015;39 Supl 1:105-24.

21. Santos JC, Binow AM, Santos ST. Estudo da incidência de casos de leishmaniose tegumentar americana no município de Espigão do Oeste - RO. Rev Enferm Saude Colet. 2016;2:15-28.

22. Graziani D, Oliveira VA, Silva RC. Estudo das características epidemiológicas da leishmaniose tegumentar americana no estado de Goiás, Brasil, 2007-2009. Rev Patol Trop. 2013;42:417-24.

23. Sampaio RN, Gonçalves MC, Leite VA, França BV, Santos G, Carvalho MS, et al. Estudo da transmissão da leishmaniose tegumentar americana no Distrito Federal. Rev Soc Bras Med Trop. 2009;42:686-90.

24. Nascimento AP, Alves JB, Cardoso VS, Brito WI. Aspectos epidemiológicos da leishmaniose tegumentar americana no município de Primavera do Leste, Mato Grosso, MT, Brasil. Saude Colet. 2011;8:210-4.

25. Rocha TJ, Santana EP, Barbosa AC, Calheiros CM. Aspectos epidemiológicos dos casos humanos confirmados de leishmaniose tegumentar americana no Estado de Alagoas, Brasil. Ver Pan-Amaz Saude. 2015;6:49-54.

26. Xavier KD, Mendes FC, Rossi-Barbosa LA. Leishmaniose tegumentar americana: estudo clínico-epidemiológico. Rev Univ Vale do Rio Verde. 2016;14:1210-22.

27. Moreira C, Segundo AS, Carvalhosa AA, Estevame LS, Pereira SA, Aguilar AM. Comportamento geoespacial da leishmaniose tegumentar americana no município de Tangará da Serra - MT. J Health Sci. 2016;18:171-6.

28. Silva-Nunes M, Cavasini CE, Silva NS, Galati EA. Epidemiologia da leishmaniose tegumentar e descrição das populações de flebotomíneos no município de Acrelândia, Acre, Brasil. Rev Bras Epidemiol. 2008;11:241-51.

29. Azeredo-Coutinho RB, Mendonça SC. An intermittent schedule is better than continuous regimen of antimonial therapy for cutaneous leishmaniasis in the municipality of Rio de Janeiro, Brazil. Rev Soc Bras Med Trop. 2002;35:477-81.

30. Pelissari DM, Checinel MP, Sousa-Gomes ML, Lima Júnior FE. Tratamento da leishmaniose visceral e leishmaniose tegumentar americana no Brasil. Epidemiol Serv Saude. 2011;20:107-10.

31. Andrade Filho JD, Valente MB, Andrade WA, Brazil RP, Falcão AL. Flebotomíneos do Estado de Tocantins, Brasil (Diptera: Psychodidae). Rev Soc Bras Med Trop. 2001;34:323-9.

32. Balian RP, Alves JV, Matos GG, Guimarães JP, Pereira LI, Pinto AS, et al. Epidemiologia molecular da leishmaniose tegumentar 
americana da Região Centro-Oeste. Rev Patol Trop. 2013;42 Supl 1:74.

33. Naiff MF, Cupolillo E, Naiff RD, Momen H, Barret TV, Grimaldi Júnior G. Leishmaniose tegumentar americana na Amazônia: distribuição geográfica dos agentes etiológicos na região. Rev Soc Bras Med Trop. 1999;32 Supl 1:243.

34. Tocantins. Secretaria da Fazenda. Balanço geral consolidado. [cited 2017 Nov 8]. Available from: http://www2.sefaz.to.gov. br/balanco/2015/pdf/7_balanco_social.pdf
35. Prefeitura Municipal de Palmas. Secretaria de Saúde. Saúde realiza I Simpósio de Vigilância às Zoonoses e II Fórum de Discussão das Leishmanioses. [cited 2017 Nov 7]. Available from: http://www.palmas.to.gov.br/secretaria/saude/ noticia/1500511/saude-realiza-i-simposio-de-vigilancia-aszoonoses-e-ii-forum-de-discussao-das-leishmanioses/ 